Int. J. Morphol.,

36(3):881-885, 2018

\title{
Oxidative Stress and Sex Difference in Liver of Rats Exposed to Cyclohexanone
}

\author{
Estrés Oxidativo y Diferencia Sexual en el Hígado de Ratas Expuestas a Ciclohexanona
}

\author{
Yong-Hoon Lee, Cheol-Hong Lim \& Yong Hyun Chung
}

LEE, Y. H.; LIM, C. H. \& CHUNG, Y. H. Oxidative stress and sex difference in liver of rats exposed to cyclohexanone. Int. J. Morphol., 36(3):881-885, 2018.

SUMMARY: Cyclohexanone is widely used in industry for the organic synthesis of chemicals such as adipic acid, caprolactam, polyvinyl chloride and its copolymers, and methacrylate ester polymers. Its mechanism of toxicity, especially oxidative stress, is rarely reported in cyclohexanone toxicity studies. In this study, we evaluate oxidative stress immunohistochemically in the livers of rats exposed to cyclohexanone. Rats were exposed to $0 \mathrm{ppm}$ and $625 \mathrm{ppm}$ cyclohexanone for $6 \mathrm{~h} / \mathrm{day}$, 5 days/week, for 13 weeks via whole-body inhalation. All rats were sacrificed at the end of exposure and livers were removed and prepared for histological examination. Histopathology indicated an increase in bile duct hyperplasia in the liver was only observed in the cyclohexanone-exposed group, compared to that in the control group in males. Immunohistochemistry showed 4-HNE immunoreactivity in the cytoplasm of hepatocytes in the liver. Immunoreactivity was significantly stronger in the cyclohexanone-exposed group compared to the control group in both sexes. However, it was significantly stronger in males compared to females. This result shows a sex-based difference in the expression of oxidative stress in response to cyclohexanone exposure.

KEY WORDS: Cyclohexanone; 4-HNE; Immunohistochemistry.

\section{INTRODUCTION}

Cyclohexanone is an oily liquid that is mainly used in industrial chemical production for the organic synthesis of adipic acid, caprolactam, polyvinyl chloride and its copolymers, and methacrylate ester polymers (OECD, 1996). In 2014, 256,931 tons were manufactured in Korea, exposing 8,399 workers (KOSHA, 2014). Also, Europe manufactures or imports over 1,000,000 tons of it per year (ECHA, 2017). The current permissible exposure limit for Cyclohexanone established by the Occupational Safety and Health Administration is a concentration of $25 \mathrm{ppm}$ over an eight hour time-weighted average (TWA) (OECD).

Inhalation exposure leads to central nervous system depression, the irritation to respiratory system, the eye and skin in human (New Jersey Department of Health, 2009). In addition, liver and kidney damage has been reported in humans as well as rabbits and monkeys (Cralley 1985; U. S. Department of Health and Human Services, 1988; IARC, 2018).
Oxidative stress results from an imbalance between the production of oxidizing species and antioxidants. Reactive oxygen species (ROS) may be harmful to cells, causing formation of radical products whose accumulation is associated with numerous diseases (Evans \& Cooke, 2004). Oxidative stress may be mechanistically related to the toxicity some industrial chemicals. For example, trichloroethylene is used in industry as a general solvent, primarily for degreasing metal parts. It causes oxidative stress in the liver and kidney, which can increase the risk of cancer in laboratory animals and humans (Lock \& Reed, 2006; Chen, 2000).

However, oxidative stress effect are rarely reported in cyclohexanone toxicity studies. In this study, we aimed to characterize the oxidative stress in the livers of rats exposed to cyclohexanone with immunohistochemistry.

Inhalation Toxicity Research Center, Chemical Research Bureau, Occupational Safety and Health Research Institute, Korea Occupational Safety and Health Agency, Daejeon 305-380, Republic of Korea.

This work was supported by the Korea Occupational Safety and Health Agency, Ministry of Labor, Republic of Korea, and a Grant-in-Aid for chemical hazard assessment, 2017. 


\section{MATERIAL AND METHOD}

Forty specific-pathogen-free (SPF) F344 rats (20 males and 20 females) were divided into control group $(0$ $\mathrm{ppm})$ and cyclohexanone exposed group (625 ppm) (10 per sex per group). The rats were purchased from Japan SLC Inc. (Shizuoka, Japan).They had free access to a commercial rodent diet (Teklad Global 18 \% Protein Rodent Diet, Envigo Co., Huntingdon, UK) and filtered tap water. All rats were individually housed in stainless steel wire mesh cages (W $230 \mathrm{~mm} ¥ \mathrm{~L} 1200 \mathrm{~mm} ¥ \mathrm{H} 200 \mathrm{~mm}$ ). A whole-body exposure chamber (WITC-00-M, HCT Co., Icheon, Korea), with a gas generator (LVg-04-A, HCT Co., Icheon, Korea), was used to expose the rats to cyclohexanone at 0 and $625 \mathrm{ppm}$ for $6 \mathrm{~h} /$ day, 5 days/week for 13 weeks. The chamber conditions, including temperature, relative humidity, pressure, and air ventilation, were controlled with an environmental controller (WITC-00-M, HCT Co., Icheon, Korea). The protocols used in the study were reviewed and approved by the Institutional Animal Care and Use Committee (IACUC-1710).

Tissue preparation for light microscopy. At 13 weeks of treatment, rats were euthanized. Livers were surgically removed from each animal during necropsy and fixed immediately in $10 \%$ neutral buffered formalin. Livers were processed routinely, embedded in paraffin, sectioned to 3-4 $\mathrm{mm}$, stained with hematoxylin and eosin, and examined microscopically under low- to high- power fields.

Immunohistochemical staining. Sections were deparaffinized and blocked for endogenous peroxidase activity with $3 \% \mathrm{H}_{2} \mathrm{O}_{2}$ for $10 \mathrm{~min}$, boiled in $0.1 \mathrm{M}$ citric

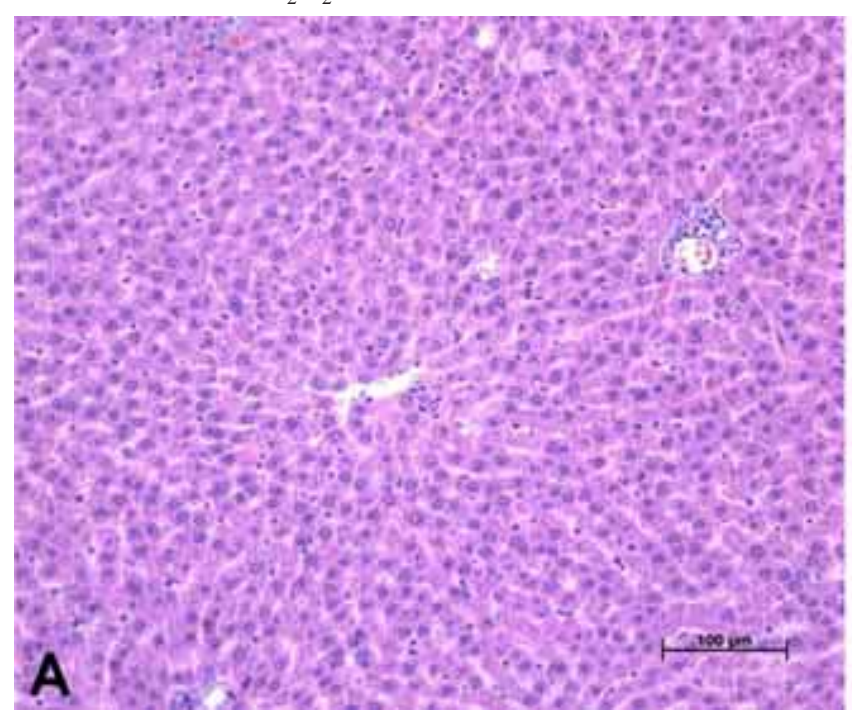

acid buffer for $10 \mathrm{~min}$, and treated with universal blocking reagent (Bio Genex, San Ramon, CA, USA) for $10 \mathrm{~min}$ at room temperature to eliminate nonspecific binding. Sections were incubated with 1:100 rabbit polyclonal anti-4hydroxynonenal (4-HNE) antibody (Abcam, Cambridge, UK) overnight at $4{ }^{\circ} \mathrm{C}$. Signals were developed with an avidin-biotin horseradish peroxidase complex and diaminobenzidine (DAB) chromogen using the RealTM EnvisonTM Detection system (Dako, Glostrup, Denmark). Sections were counterstained with Mayer's hematoxylin for 30 s, dehydrated, covered with coverslip and examined by light microscopy. The intensity of staining was scored from 0 to 5 (0: No staining, $1:<10 \%, 2: 10-30 \%, 3: 30-50 \%, 4$ : 50-70\%, 5: >70\%).

Statistical Analysis. Immunoreactivity scores were evaluated using SPSS (ver. 19.0, IBM, Chicago, IL, USA). The MannWhitney $\mathrm{U}$ test was used to assess statistical significance. $\mathrm{P}$ values below 0.05 indicated statistical significance.

\section{RESULTS}

Histopathology showed an increase of bile duct hyperplasia in the livers of the male was observed in cyclohexanone-exposed group compared to control group (Table I) (Fig. 1). However, abnormal lesions were not observed in the livers of the female control or cyclohexanoneexposed groups.

Immunohistochemistry showed that, in males, 4-HNE was strongly expressed in the cytoplasm of almost every hepatocyte of hepatic lobules of the cyclohexanone-exposed

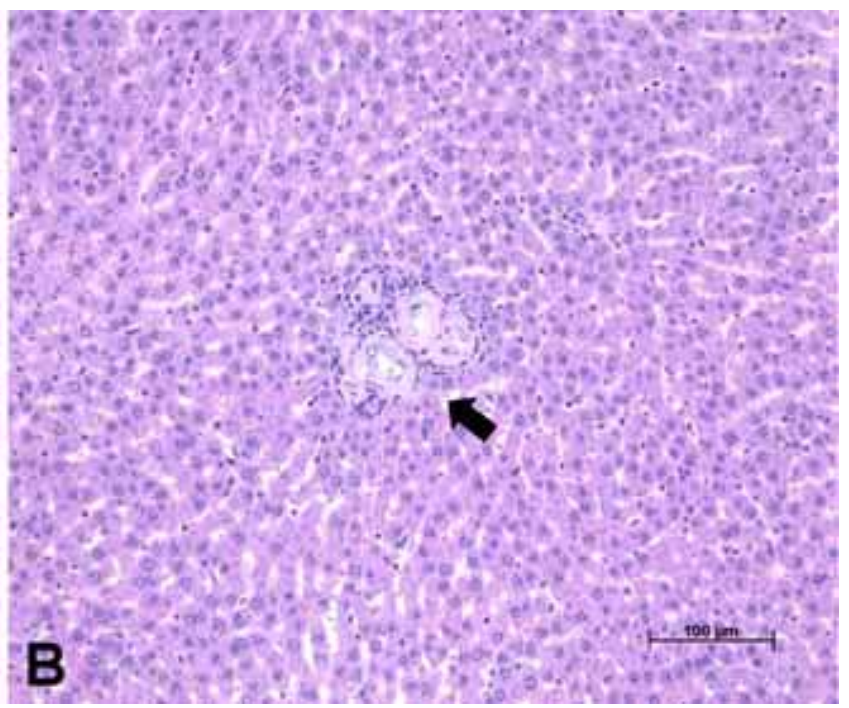

Fig. 1. Histological findings in livers of male rats exposed to cyclohexanone. A) No abnormal lesions were observed in control group livers, B) Bile duct hyperplasia at portal tract (arrow) was observed in the cyclohexanone-exposed group (625 ppm). Magnification x200. 
Table I. Incidence of bile duct hyperplasia in liver.

\begin{tabular}{llcc}
\hline Findings & Grade & Control $(0 \mathrm{ppm})$ & Cyclohexanone $(625 \mathrm{ppm})$ \\
\hline Bile duct hyperplasia & Minimal & $1 / 10$ & $2 / 10$ \\
& Mild & $1 / 10$ & $2 / 10$ \\
& Total & $2 / 10$ & $4 / 10$ \\
\hline
\end{tabular}

group, while it was expressed mainly in the cytoplasm of hepatocytes around the central vein of hepatic lobules in the control group. In particular, 4-HNE was strongly observed in hepatocytes around bile duct hyperplasia in the cyclohexanoneexposed group compared to the control group. In contrast to males, 4-HNE was weakly expressed in females in the cytoplasm of hepatocytes around central vein of hepatic lobules in the cyclohexanone-exposed group, while it was faintly expressed in the cytoplasm of hepatocytes around central vein of hepatic lobules in the control group (Fig. 2).

With semi-quantitative scoring, 4-HNE expression was significantly stronger in the cyclohexanone-exposed group compared to the control group in both sexes. However, it was significantly stronger in male groups compared to female groups (Fig. 3).
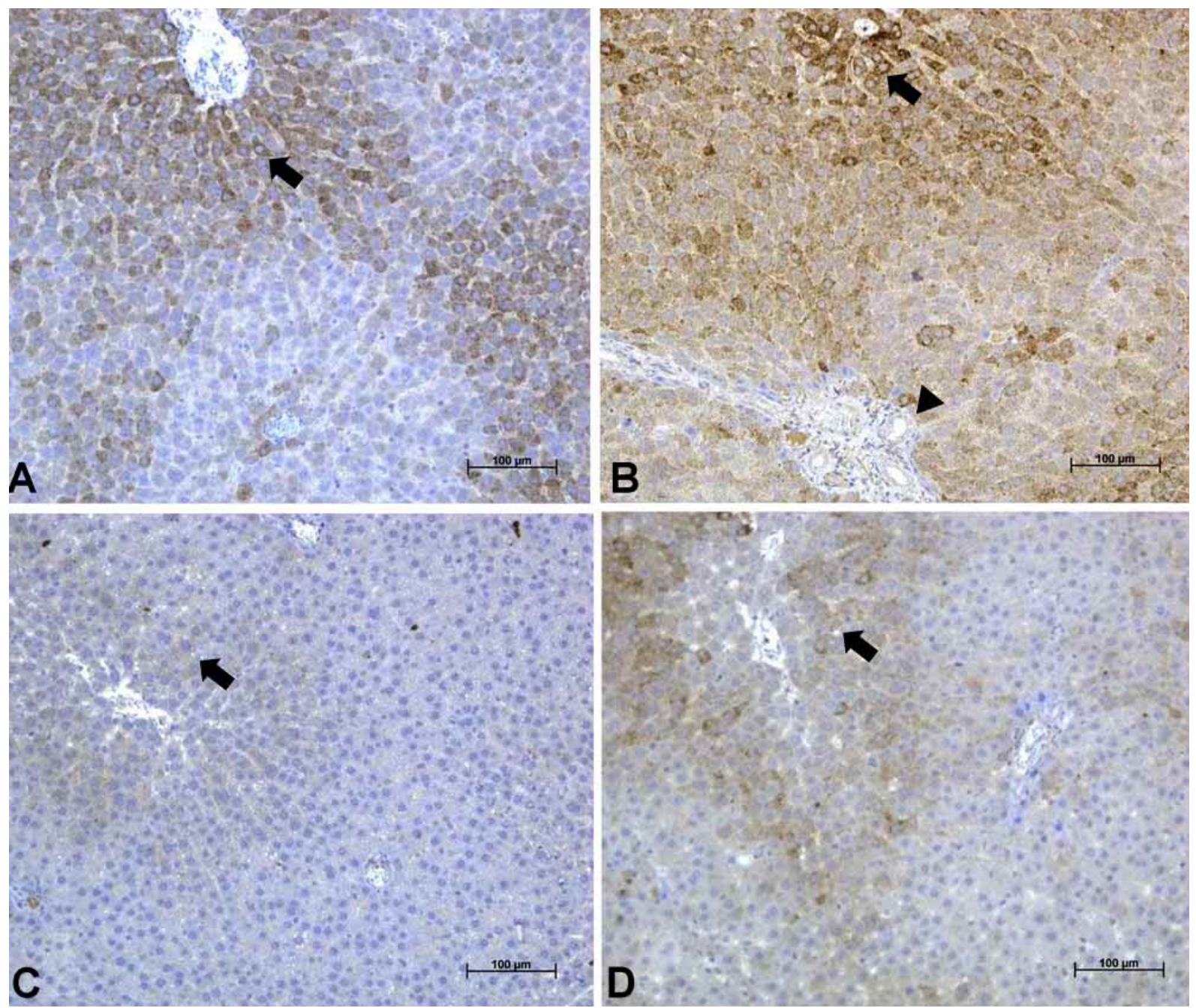

Fig. 2. Immunohistochemical detection of 4-HNE expression in livers of control and cyclohexanone-exposed groups. In males, A) immunoreactivity of 4-HNE was observed mainly in the cytoplasm of hepatocytes around central vein of hepatic lobules in the control group (arrow), B) 4-HNE was strongly expressed in the cytoplasm of most hepatocyte of hepatic lobule in the cyclohexanone-exposed group (arrow). 4-HNE expression in hepatocytes near bile duct hyperplasia at the portal tract (arrow head). In females, C) 4-HNE was faintly expressed in the cytoplasm of hepatocytes around central vein of hepatic lobule in the control group (arrow). D) 4-HNE was weakly expressed in the cytoplasm of hepatocyte around central vein of hepatic lobule in the cyclohexanone-exposed group (arrow). Magnification x200. 


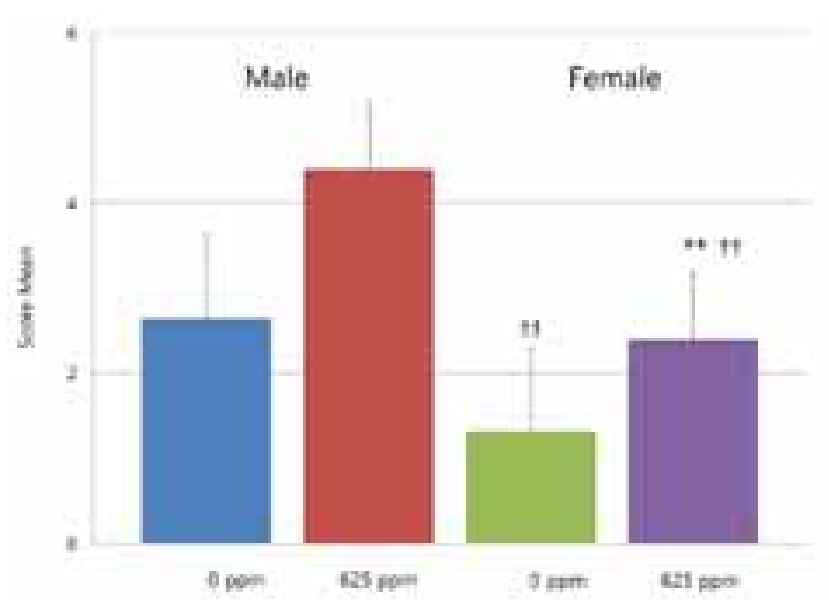

Fig. 3. Semiquantitative Score of 4-HNE immunoreactivity in liver Significant differences compared with control group: $* * p<0.01$. Significant differences compared with equivalent exposure male rat group : $\uparrow \dagger \mathrm{p}<0.01$

\section{DISCUSSION}

In this study, increased bile duct hyperplasia in the liver was only observed in males in the cyclohexanoneexposed group (Table I). These changes, known as background lesions, are usually found in older animals in rats and mice, but might be induced or exacerbated by the treatment in this study, as indicated by the incidence difference of the lesions between control and cyclohexanoneexposed groups (Thoolen et al., 2010).

Oxidative stress arises from an imbalance in the production neutralization and metabolism of ROS, resulting in the formation of free radicals (Evans \& Cooke). Lipid peroxidation results from hydroxyl radical attack on fatty acyl chains of phospholipids and triglycerides (Brand, 2010; Sena \& Chandel, 2012). 4-HNE is one of the major end products of lipid peroxidation, and it is associated with pathogenesis in a variety of diseases including Alzheimer's disease, cataract, and cancer (Esterbauer et al., 1991; Uchida, 2003). Several studies have revealed that the carbon-carbon double bond of 4-HNE can react with a variety of cellular components, including DNA and proteins (Uchida \& Stadtman, 1992). Also, 4-HNE is a strong electrophile that can change cellular redox state significantly by decreasing cellular sulfhydryl compounds such as glutathione (GSH). Therefore, 4-HNE has been acknowledged as a mediator and inducer of oxidative stress (Awasthi et al., 2004). Also, 4-HNE has demonstrated induction of oxidative stress by immunohistochemistry in tissue obtained from animals treated with ethanol, iron combined with ethanol, or carbon tetrachloride (Tsukamoto et al., 1995; Hartley et al., 1997; Kono et al., 2001). Therefore, 4-HNE is an useful immunohistochemical marker for evaluating oxidative stress.

Immunohistochemistry showed that 4-HNE was more strongly expressed in the cytoplasm of hepatocytes in the cyclohexanone-exposed group than in control group in both sexes. Also, 4-HNE expression in the liver was stronger in the male groups compared to the female groups. This result indicates that the exposure to cyclohexanone caused oxidative stress in hepatocytes of liver and although bile ducts do not express positive signals, increased bile duct hyperplasia can also be caused by oxidative stress because hepatocytes around bile ducts express positive signals to a considerable degree. A previous study linked cyclohexanone treatment to acute liver damage. In rat induced with carbon tetrachloride, enhanced liver damage may have been caused by free radical oxygen that increased with cyclohexanone treatment (Kim et al., 2002), which supports our results. Differences between sexes in 4-HNE expression in the liver may be attributed to sexual dimorphism in cytochrome P450 that is associated with the metabolism of xenobiotics (Borrás et al., 2003; Cederbaum, 2015).

In conclusion, the present study revealed oxidative stress in the livers of rats exposed to cyclohexanone, with different results observed based on sex. This provides useful information on the toxic mechanism of cyclohexanone.

LEE, Y. H.; LIM, C. H. \& CHUNG, Y. H. Estrés oxidativo y diferencia sexual en el hígado de ratas expuestas a ciclohexanona. Int. J. Morphol., 36(3):881-885, 2018.

RESUMEN: La ciclohexanona se usa ampliamente en la industria para la síntesis orgánica de sustancias químicas, como el ácido adípico, la caprolactama, el cloruro de polivinilo y sus copolímeros y los polímeros del éster metacrilato. Su mecanismo de toxicidad, especialmente el estrés oxidativo, se observa raramente en los estudios de toxicidad de la ciclohexanona. En el presente estudio, evaluamos el estrés oxidativo a través de la inmunohistoquímica en hígados de ratas expuestas a la ciclohexanona. Las ratas fueron expuestas a 0 ppm y $625 \mathrm{ppm}$ de ciclohexanona por 6 horas diarias, 5 días a la semana durante 13 semanas, mediante inhalación corporal total. Al final de la exposición, se sacrificaron las ratas y se extirparon sus hígados para el examen histológico. La histopatología indicó que se observó un aumento de la hiperplasia del conducto biliar solamente en el grupo expuesto a la ciclohexanona, en comparación con el grupo de control en machos. La inmunohistoquímica mostró una inmunorreactividad al 4-HNE en el citoplasma de los hepatocitos del hígado. La inmunorreactividad fue significativamente mayor en el grupo expuesto a la ciclohexanona, en comparación con el grupo control en ambos sexos. Sin embargo, fue significativamente 
mayor en los machos, en comparación con el hígado de las hembras. Este resultado muestra una diferencia basada en el sexo, en la expresión del estrés oxidativo en respuesta a la exposición a la ciclohexanona.

PALABRAS CLAVE: Ciclohexanona; 4-HNE; Inmunohistoquímica.

\section{REFERENCES}

Awasthi, Y. C.; Yang, Y.; Tiwari, N. K.; Patrick, B.; Sharma, A.; Li, J. \& Awasthi, S. Regulation of 4-hydroxynonenal-mediated signaling by glutathione S-transferases. Free Radic. Biol. Med., 37(5):607-19, 2004.

Borrás, C.; Sastre, J.; García-Sala, D.; Lloret, A.; Pallardó, F. V. \& Viña, J. Mitochondria from females exhibit higher antioxidant gene expression and lower oxidative damage than males. Free Radic. Biol. Med., 34(5):546-52, 2003.

Brand, M. D. The sites and topology of mitochondrial superoxide production. Exp. Gerontol., 45(7-8):466-72, 2010.

Cederbaum, A. I. Molecular mechanisms of the microsomal mixed function oxidases and biological and pathological implications. Redox Biol., 4:60-73, 2015.

Chen, C. W. Biologically based dose-response model for liver tumors induced by trichloroethylene. Environ. Health Perspect., 108 Suppl. 2:335-42, 2000.

Cralley, L. J. Patty's Industrial Hygiene and Toxicology. Volume III: Theory and Rationale of Industrial Hygiene Practice. 3A: The Work Environment. $2^{\text {nd }}$ ed. New York, John Wiley Sons, 1985. pp.164.

Esterbauer, H.; Schaur, R. J. \& Zollner, H. Chemistry and biochemistry of 4-hydroxynonenal, malonaldehyde and related aldehydes. Free Radic. Biol. Med., 11(1):81-128, 1991.

European Chemicals Agency (ECHA). Substance evaluation conclusion as required by REACH Article 48 and Evaluation Report for Cyclohexanone. EC No 203-631-1. CAS No 108-94-1. Evaluating Member State(s): Poland. Lodz, Bureau for Chemical Substances, 2017. Available from: https://echa.europa.eu/documents/10162/498f85b38457-f41a-ab02-d8db0d6fc8ae

Evans, M. D. \& Cooke, M. S. Factors contributing to the outcome of oxidative damage to nucleic acids. Bioessays, 26(5):533-42, 2004.

Hartley, D. P.; Kroll, D. J. \& Petersen, D. R. Prooxidant-initiated lipid peroxidation in isolated rat hepatocytes: detection of 4-hydroxynonenaland malondialdehyde-protein adducts. Chem. Res. Toxicol., 10(8):895905, 1997.

International Agency for Research on Cancer (IARC). IARC Monographs on the Evaluation of the Carcinogenic Risks to Humans. Lyon, World Health Organization, International Agency for Research on Cancer, 2018. Available from: http://monographs.iarc.fr/ENG/Classification/ index.php.

Kim, H. H.; Joh, H. S. \& Yoon, C. G. Effect of cyclohexanone treatment on the activities of oxygen free radical metabolizing enzyme in the liver damaged rats. Korean J. Environ. Health Sci., 28(2):81-8, 2002.

Kono, H.; Arteel, G. E.; Rusyn, I.; Sies, H. \& Thurman, R. G. Ebselen prevents early alcohol-induced liver injury in rats. Free Radic. Biol. Med., 30(4):403-11, 2001.

Korea Occupational Safety and Health Agency (KOSHA). Work Environment Survey in 2014. Ulsan, Korea Occupational Safety and Health Agency (KOSHA), 2014. Available from: http:// www.kosha.or.kr/content.do?menuId=10260

Lock, E. A. \& Reed, C. J. Trichloroethylene: mechanisms of renal toxicity and renal cancer and relevance to risk assessment. Toxicol. Sci., 91(2):313-31, 2006.
New Jersey Department of Health. Hazardous Substance Fact Sheet. Common Name: Cyclohexanone. New Jersey, New Jersey Department of Health, 2009. Available from: http://nj.gov/health/eoh/rtkweb/ documents/fs/0570.pdf

Organisation for Economic Co-operation and Development (OECD). Cyclohexanone. CAS N ${ }^{\circ}$ : 108-94-1. Paris, OECD Screening Information DataSet (SIDS) High Production Volume Chemicals, 1996. Available from: http://www.inchem.org/documents/sids/sids/108941.pdf

Sena, L. A. \& Chandel, N. S. Physiological roles of mitochondrial reactive oxygen species. Mol. Cell, 48(2):158-67, 2012.

Thoolen, B.; Maronpot, R. R.; Harada, T.; Nyska, A.; Rousseaux, C.: Nolte, T., Malarkey, D. E.: Kaufmann, W.; Küttler, K.; Deschl, U.; Nakae, D.; Gregson, R.; Vinlove, M. P.; Brix, A. E.; Singh, B.; Belpoggi, F. \& Ward, J. M. Proliferative and nonproliferative lesions of the rat and mouse hepatobiliary system. Toxicol. Pathol., 38(7 Suppl.):5S-81S, 2010.

Tsukamoto, H.; Horne, W.; Kamimura, S.; Niemelä, O.; Parkkila, S.; YläHerttuala, S. \& Brittenham, G. M. Experimental liver cirrhosis induced by alcohol and iron. J. Clin. Invest., 96(1):620-30, 1995.

U. S. Department of Health and Human Services. Occupational Safety and Health Guidelines for Cyclohexanone. Washington D. C., Public Health Service, Centers for Disease Control and Prevention (CDC), National Institute for Occupational Safety and Health (NIOSH), 1988. Available from: https://www.cdc.gov/niosh/docs/81-123/pdfs/0166.pdf.

Uchida, K. \& Stadtman, E. R. Modification of histidine residues in proteins by reaction with 4-hydroxynonenal. Proc. Natl. Acad. Sci. U. S. A., 89(10):4544-8, 1992.

Uchida, K. 4-Hydroxy-2-nonenal: a product and mediator of oxidative stress. Prog. Lipid Res., 42(4):318-43, 2003.

\author{
Corresponding author: \\ Dr. Yong-Hoon Lee \\ Inhalation Toxicity Research Center \\ Chemical Research Bureau \\ Occupational Safety and Health Research Institute \\ Korea Occupational Safety and Health Agency \\ 339-30 Expo-ro, Yuseong-gu \\ Daejeon 34122 \\ REPUBLIC OF KOREA
}

\section{E-mail: dvmone@kosha.or.kr}

Received: 14-03-2018

Accepted: 23-04-2018 